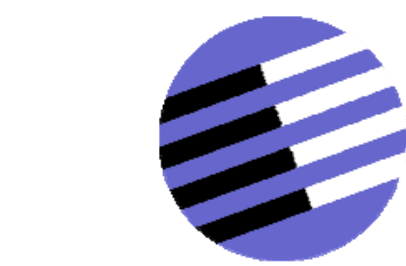

GOVERNANCE AND THE EFFICIENCY

OF ECONOMIC SYSTEMS

GESY

\begin{tabular}{|} 
Discussion Paper No. 213 \\
Who is Afraid of Political Risk? \\
Multinational Firms and their \\
Choice of Capital Structure \\
Iris Kesternich* \\
Monika Schnitzer **
\end{tabular}

August 2007

*I ris Kesternich, University of Munich, Department of Economics, Ludwig Str. 28 Rg,

80539 Munich, Germany,

Phone: +49-89-2180-3955, Fax: +49-89-2180-3954

Iris.Kesternich@Irz.uni-muenchen.de

**Monika Schnitzer, University of Munich, Department of Economics, Akademiestr. 1/III,

80799 Munich, Germany,

Phone: +49-89-2180-2217, Fax: +49-89-2180-2767

schnitzer@Irz.uni-muenchen.de

Financial support from the Deutsche Forschungsgemeinschaft through SFB/TR 15 is gratefully acknowledged.

Sonderforschungsbereich/Transregio $15 \cdot$ www.gesy.uni-mannheim.de

Universität Mannheim . Freie Universität Berlin · Humboldt-Universität zu Berlin · Ludwig-Maximilians-Universität München Rheinische Friedrich-Wilhelms-Universität Bonn · Zentrum für Europäische Wirtschaftsforschung Mannheim 


\title{
Who is Afraid of Political Risk? Multinational Firms and their Choice of Capital Structure
}

\author{
Iris Kesternich* and Monika Schnitzer**
}

August 2007

\begin{abstract}
This paper investigates how multinational firms choose their capital structure in response to political risk. We focus on two choice variables, the leverage and the ownership structure of the foreign affiliate, and we distinguish different types of political risk, like expropriation, corruption and confiscatory taxation, and In our theoretical analysis we find that as political risk increases the ownership share always decreases whereas leverage can both increase or decrease, depending on the type of political risk. Using the Microdatabase Direct Investment of the Deutsche Bundesbank, we find supportive evidence for these different effects.
\end{abstract}

Keywords: Multinational firms, political risk, capital structure, leverage, ownership structure

JEL: F23, F21, G32

* University of Munich, Department of Economics, Ludwigstr. 28 Rg, D-80539 Munich, Germany. Phone: +49 892180 3955, Fax: +49 892180 3954,

e-mail: Iris.Kesternich@lrz.uni-muenchen.de

** University of Munich, Department of Economics, Akademiestr. 1/III, D-80799 Munich, Germany, and Centre for Economic Policy Research. Phone: +49 892180 2217, Fax: +49 8921802767 ,

e-mail: schnitzer@lrz.uni-muenchen.de

This paper has partly been written during visits of the authors to the research centre of the Deutsche Bundesbank. The hospitality of the Bundesbank as well as access to its Microdatabase Direct Investment (MiDi) are gratefully acknowledged. The project has benefited from financial support through the German Science Foundation under SFB-Transregio 15. The authors would like to thank Christian Arndt, Theo Eicher, Florian Heiss, Matthias Schündeln, Joachim Winter, and Bernard Yeung for helpful comments and suggestions. 


\section{Introduction}

Multinational enterprises (MNE) have to adapt their optimal investment strategy to local conditions worldwide. Most notably, they have to respond to different political environments that may give rise to varying political risks at different locations. Political risk encompasses 'sovereign risk', the risk that the sovereign will interfere with a firm's ability to pay its investors as promised, but also other forms of political, economic and country specific risks that affect the profitability of an investment in a foreign country and that would not be present if the country had a more stable and developed business environment and legal institutions (Hill (1998) and Buckley (1992)). It ranges from outright expropriation to more subtle forms like confiscatory taxation, corruption or economic constraints like exchange rate controls. MNE can try to insure against political risk, but they can never do so fully ${ }^{1}$

In this paper we investigate both theoretically and empirically how MNE choose their capital structure in response to political risk. For this purpose we distinguish different types of political risk. We find that it is important to identify which type prevails in a particular country because different types of risk affect the optimal financing decision in different ways.

We focus on two choice variables that determine the capital structure, the level of leverage and the ownership structure of the foreign affiliate. A foreign investor chooses his ownership share in order to maximize his expected payoff from the foreign investment, taking into account that a larger ownership share means both more cash flow rights and a larger amount of equity to be invested in the project. Less equity is needed if the firm is more highly levered. The more levered the project, however, the more likely it is that the credits cannot be served and the project has to file for bankruptcy, involving some bankruptcy cost. The investor optimally balances the costs arising from equity and debt financing. Therefore, the optimal capital structure has both ownership share and leverage move together, i.e. larger ownership share goes hand in hand with higher leverage.

\footnotetext{
${ }^{1}$ First, the insurance market for political risk is incomplete because most types of political risk are incontractible and because the market suffers from severe asymmetric information (see for example Desai, Foley and Hines (2006)). Second, many investors are unaware of the existence of political risk insurance and even those who are aware of its existence often do not hold such an insurance (www.political-risk.net).
} 
Throughout the paper, we distinguish three prototypes of political risk. ${ }^{2}$ In Scenario I, political risk takes the form of outright expropriation or nationalization where the investor loses all assets and cannot serve his credits anymore. This type of political risk used to be of significant importance in the past but is less prevalent nowadays (Kobrin (1980), Andersson (1991)).

Scenario II captures political risk as a form of creeping expropriation that lowers the expected returns of the project. Potential forms could be a lack of protecting intellectual property rights or outright corruption, but also imposing economic constraints like currency or exchange rate controls or particular regulatory requirements that can be directed at foreign multinationals. Political violence that negatively affects market conditions and hence expected revenues would be another example.

In Scenario III, we capture political risk that affects directly the profits of the investment, i.e. after serving potential debt payments. This type of political risk arises if the host country imposes discriminating and confiscatory taxation or is blocking the repatriation of funds from the host country to the home country.

Our analysis shows that these different forms of political risk affect the expected profitability of the investment in very different ways and can therefore cause the multinational to choose very different capital structures. We find that in all three scenarios the optimal ownership share decreases as the level of political risk increases. But this is very different for the leverage choice. The optimal debt level decreases with increasing political risk in both Scenarios I and II but tends to increase with political risk in Scenario III.

We investigate further how the two choices, ownership share and leverage, interact. For this purpose, we determine the direct effect of political risk on each of the two variables, holding fixed the other variable. We then determine the total effect, that includes also the indirect effect via the interaction with the other variable. As both variables tend to move together, we find that the relative strength of the total effects are weaker than the direct effects if the direct effects have opposite signs and hence mitigate each other. They are stronger if the direct effects have the same sign and thus reinforce each other.

In our empirical analysis we use the Microdatabase Direct Investment (MiDi) of the Deutsche Bundesbank to investigate the impact of political risk on both the choice of ownership shares and leverage of foreign affiliates of German multinationals. The dataset

\footnotetext{
${ }^{2}$ For a description of various forms of political risks see Buckley (1992), Hill (1998)
} 
contains balance sheet information on the foreign affiliates. German parents are by law required to report this information when the balance sheet total of the affiliate and the ownership share are larger than a certain threshold. As a measure for political risk we use the time-varying, country specific index that is provided by the International Country Risk Guide (ICRG).

In a first step, we estimate the impact of political risk on our two choice variables separately. Our ownership regression indicates that MNEs hold a smaller share of the equity of the foreign affiliate when political risk is high, confirming our theoretical predictions. Regarding the leverage choice, we find that affiliates of MNE use a higher level of debt in countries with a higher level of political risk, indicating the prevalence of Scenario III type of political risk. Our theoretical model predicts, however, that ownership and leverage are not independent of each other. Therefore, the coefficients in the seperate regressions capture the sum of the direct effects of the covariates and the indirect effect via the left-out variable.

To analyze both direct effects as well as the relationship between the ownership share and the level of leverage, we include the level of leverage in the regression of the ownership share. As the two variables are determined simultaneously, we use the technique of instrumental variables estimation to overcome potential biases that stem from this simultaneity. Our instrumental variable analysis confirms that there is a positive relationship between the level of leverage and the ownership share. As predicted by our theoretical model for all types of political risk, the direct effect of political risk on ownership is negative also in our data.

Finally, we attempt to capture the effects of different types of political risk. We find that indeed for less severe types of political risk, leverage increases with political risk, whereas it decreases with more severe types, as predicted by our theoretical analysis.

Our paper is related to two strands of literature, the literature on political risk and the literature on the capital structure choice.

The first strand of literature studies the effects of political risk on foreign direct investment. The early theoretical papers were primarily concerned with the question how foreign direct investment can be sustained if there is a risk of nationalization. The seminal paper in this literature is Eaton and Gersovitz (1983) showing under what circumstances reputation can sustain foreign direct investment. Other papers study how political risk 
affects the multinational's investment strategy. It may induce the investor to choose an inefficient technology (Eaton (1995)), inefficient investment paths (Thomas and Worrall (1994), and Schnitzer (1999)) or excess capacity (Janeba (2000)). More recent papers have investigated the sale of shares to locals as a possible way to mitigate the risk of confiscatory taxation or creeping expropriation (Konrad and Lommerud (2001), Mueller and Schnitzer (2006)). However, none of these authors have allowed for different forms of political risk to impact the investor's decisions in different ways. Empirical studies have focussed on the question how country characteristics affect the ownership structure in foreign direct investment projects (Asiedu and Esfahani (2001)).

The second strand of literature has so far mainly focused on taxes as the driving force behind the capital structure choice. It has been shown both empirically and theoretically that tax incentives lead to national differences in the level of leverage of affiliates of MNE (see for example Desai, Foley, and Hines Jr. (2004), Huizinga, Laeven, and Nicodeme (2006) and Buettner, Overesch, Schreiber, and Wamser (2006)). However, there is much less evidence on how differing levels of political risk may affect the capital structure of affiliates that are located in different countries. Desai, Foley and Hines (2004) find for US data that political risk increases affiliate leverage. Aggarwal and Kyaw (2004) also use US data, but in a more aggregated level. However, in contrast to Desai, Foley and Hines they find that political risk reduces affiliate leverage. They also find that higher political risk increases local interest rates. Novaes and Werlang (2005) study foreign affiliates in Brazil and find that they are more highly levered than their Brazilian counterparts and that the difference increases with Brazil's political risk.

This conflicting evidence suggests that the relationship between political risk and leverage is not straightforward and hence needs more examination. As our theoretical analysis suggests, the coefficient may indeed change signs, depending on the type of political risk. We find this possibility of different coefficients confirmed in our empirical analysis.

The remainder of the paper is organized as follows. Section 2 introduces our theoretical model. In Section 3 we analyze the optimal financial structure in the baseline model. Section 4 investigates the optimal financial structure in the presence of political risk. In section 5, we derive empirical predictions. Section 6 introduces the data set. In Section 7 we present our empirical results. Section 8 concludes. 


\section{Model}

Consider a multinational investor who intends to invest a fixed amount $I$ in a foreign location. The project generates a stochastic return $\mathrm{R}$, with $\mathrm{R}$ being uniformly distributed on the interval $[0, \bar{R}]$. The investment can be financed with either debt, $D$, or equity, $E$, or a combination of both, such that $E+D=I$.

The investor has to take two decisions, he has to choose how much debt finance $D$ to use and what share $\alpha$ of the equity to finance himself. With the latter decision the investor simultaneously affects his equity cost and his share of cash flow rights. For any share $\alpha$ of equity the investor contributes to the project he incurs capital cost $C(\alpha E)$. We assume that $C$ is convex in his share of equity. This assumption can be interpreted in two ways. One interpretation is that of opportunity cost. The more equity the investor contributes to the project, the more alternative projects the investor has to give up. If alternative projects have different values, then a natural assumption is that the opportunity cost increases in the number of projects not realized. A second interpretation is one of costly external finance due to adverse selection or moral hazard problems. These kind of financing frictions can be captured in a reduced form model like the one used here, as shown by Froot, Scharfstein, and Stein (1993) and Stein (1998). ${ }^{3}$.

In case of debt financing $D$ the investor's liability is restricted to the investment project. So if the investor takes up debt $D$, he has to repay $(1+r) D$, but can do so only when the project is sufficiently successful, i.e. generates returns $R \geq(1+r) D$. If the returns are not sufficient to cover the repayment, the project is liquidated. In this case the bank has the right to seize whatever returns are realized. We assume that during this bankruptcy procedure transaction costs are incurred and inefficiencies arise that allow the bank to seize only some share $s$ of the returns that are generated, with $s<1$. This assumption is supposed to capture the dead weight loss that is associated with debt financing due to the risk of bankruptcy.

Thus, both equity and debt financing are associated with increasing financing cost that need to be optimally balanced. In case of equity financing, this is captured by the convex cost function $C$, in case of debt financing, it arises due to the inefficient appropriation of returns in case of bankruptcy, leading to dead weight losses that increase with the debt

\footnotetext{
${ }^{3} \mathrm{~A}$ detailed discussion of this kind of reduced form model of costly external finance can be found in Stein (2003)
} 
level chosen.

The investment project is subject to local taxation, with tax rate $t$ being applied to the project's profits, after interest payments have been made. The investor thus maximizes the following payoff function by simultaneously choosing $\alpha$ and $D$.

$$
U_{M N E}=\int_{(1+r) D}^{\bar{R}} \alpha(1-t)[R-(1+r) D] \frac{1}{\bar{R}} d R-C(\alpha E)
$$

Banks are assumed to operate in a competitive market and to be risk neutral. Thus, for any level of debt the investor wants to be financed by banks, the interest rate $r$ is chosen such that in expected terms the banks break even.

Thus

$$
\int_{(1+r) D}^{\bar{R}}(1+r) D \frac{1}{\bar{R}} d R+\int_{0}^{(1+r) D} s R \frac{1}{\bar{R}} d R=D
$$

where $s$ represents the share of returns that can be appropriated by the bank in case of a bankruptcy procedure, as spelled out above.

The investment project is subject to political risk in the foreign location. To study how political risk affects the firm's financial structure we distinguish three different scenarios that capture different forms of political risk.

\section{Political Risk (1)}

The first scenario models political risk in the form of expropriation or nationalization. This is the classical form of political risk where a sovereign simply takes property without compensation (Buckley, 1992, Hill, 1998). We capture this form of political risk by assuming that with some probability $\pi_{1}$ the investment is expropriated, i.e. the investor loses control and cash flow rights from the investment. This leads to the following modified profit function.

$$
U_{1}=\left(1-\pi_{1}\right) \int_{(1+r) D}^{\bar{R}} \alpha(1-t)[R-(1+r) D] \frac{1}{\bar{R}} d R-C(\alpha E)
$$

Credits are served only in case the investment is not expropriated. So the zero profit condition for banks needs to be modified as well.

Thus

$$
\left(1-\pi_{1}\right)\left[\int_{(1+r) D}^{\bar{R}}(1+r) D \frac{1}{\bar{R}} d R+\int_{0}^{(1+r) D} s R \frac{1}{\bar{R}} d R\right]=D
$$




\section{Political Risk (2)}

In the second scenario we model political risk as a form of creeping expropriation or political violence that negatively affect the expected returns of the investment project. Other examples would be currency or exchange rate restrictions, a failure to enforce or respect agreed-upon property and contract rights, outright corruption and the need to pay bribes (Buckley, 1992, Hill, 1998). We capture this by a reduction of the returns $R$ that the investor is able to capture. $R$ is now uniformly distributed on the interval $\left[0,\left(1-\pi_{2}\right) \bar{R}\right]$. This leads to the following modified profit function.

$$
U_{2}=\int_{(1+r) D}^{\left(1-\pi_{2}\right) \bar{R}} \alpha(1-t)[R-(1+r) D] \frac{1}{\left(1-\pi_{2}\right) \bar{R}} d R-C(\alpha E)
$$

The expected returns of the investment project affect also the zero profit condition for banks that needs to be modified in the following way.

$$
\int_{(1+r) D}^{\left(1-\pi_{2}\right) \bar{R}}(1+r) D \frac{1}{\left(1-\pi_{2}\right) \bar{R}} d R+\int_{0}^{(1+r) D} s R \frac{1}{\left(1-\pi_{2}\right) \bar{R}} d R=D
$$

\section{Political Risk (3)}

Our third scenario captures the type of political risk that affects directly the multinational's profits. Examples would be the blocking of the repatriation of funds from the host country to the host country, or discriminating and confiscatory taxation that treats foreign firms different than domestic firms (Buckley, 1992). We model this as a form of profit tax, i.e. interest payments can be deducted and are not subject to taxation. This scenario is particularly relevant if credits are taken locally and hence the local government has no interest in jeopardizing the repayment of local credits.

$$
U_{3}=\int_{(1+r) D}^{\bar{R}} \alpha\left(1-t-\pi_{3}\right)[R-(1+r) D] \frac{1}{\bar{R}} d R-C(\alpha E)
$$

This type of political risk has no impact on the zero profit condition for banks provided the government indeed spares the interest payments from discriminating taxation.

Thus

$$
\int_{(1+r) D}^{\bar{R}}(1+r) D \frac{1}{\bar{R}} d R+\int_{0}^{(1+r) D} s R \frac{1}{\bar{R}} d R=D
$$




\section{The optimal financial structure: the base line model}

In this section we explore the base line model without political risk. The investor chooses $D$ and $\alpha$ to maximize his payoff

$$
\begin{aligned}
U_{M N E} & =\int_{(1+r) D}^{\bar{R}} \alpha(1-t)[R-(1+r) D] \frac{1}{\bar{R}} d R-C(\alpha E) \\
& =\frac{\alpha(1-t)}{\bar{R}}\left[\frac{1}{2} \bar{R}^{2}-(1+r) D \bar{R}+\frac{1}{2}(1+r)^{2} D^{2}\right]-C(\alpha E)
\end{aligned}
$$

Recall that $r$ is implicitly determined by the following condition that guarantees that banks break even in in expected terms.

$$
\int_{(1+r) D}^{\bar{R}}(1+r) D \frac{1}{\bar{R}} d R+\int_{0}^{(1+r) D} s R \frac{1}{\bar{R}} d R=D
$$

Solving and rearranging terms yields

$$
\frac{1}{2}(1+r)^{2} D^{2}=\frac{(1+r) D \bar{R}}{2-s}-\frac{\bar{R} D}{2-s}
$$

Using this in the investor's payoff function yields

$$
U_{M N E}=\alpha(1-t)\left[\frac{1}{2} \bar{R}-\frac{(1-s)(1+r)+1}{2-s} D\right]-C(\alpha E)
$$

where $r$ is implicitly determined by equation (11).

The investor's maximization problem is characterized by the following two first order conditions.

$$
\begin{aligned}
& \frac{d U}{d \alpha}=(1-t)\left[\frac{1}{2} \bar{R}-\frac{(1-s)(1+r)+1}{2-s} D\right]-(I-D) C^{\prime}=0 \\
& \frac{d U}{d D}=-\frac{\alpha(1-t)}{(2-s)}\left[(1-s)(1+r)+1+(1-s) \frac{d r}{d D} D\right]+\alpha C^{\prime}=0
\end{aligned}
$$

To guarantee that these first order conditions describe the solution to the investor's maximization problem we need to check that the determinant $|F|>0$ which is done in the 
Appendix.

Using the results of the first order condition for the optimal debt level we find that the cross derivative is positive, indicating that profit maximization yields that a larger debt level is associated with a larger ownership share and vice versa. I.e.

$$
\begin{aligned}
\frac{d^{2} U}{d \alpha d D} & =\underbrace{-\frac{1-t}{2-s}\left[(1-s)(1+r)+1+(1-s) \frac{d r}{d D} D\right]+C^{\prime}}_{=0}+(I-D) \alpha C^{\prime \prime} \\
& =(I-D) \alpha C^{\prime \prime}>0
\end{aligned}
$$

\section{The optimal financial structure and political risk}

We now investigate how political risk affects the optimal financial structure. In each of the three scenarios we distinguish direct and indirect effects of political risk. The direct effect captures the effect on, say, ownership share for a given level of debt, i.e. $\frac{\partial \alpha}{\partial \pi}$. But as the level of debt changes as well, there is also an indirect effect due to the feedback effect of the endogenous change of debt, i.e. $\frac{\partial \alpha}{\partial D} \frac{d D}{d \pi}$. The total effect captures both the direct and the indirect effect.

$$
\frac{d \alpha}{d \pi}=\frac{\partial \alpha}{\partial \pi}+\frac{\partial \alpha}{\partial D} \frac{d D}{d \pi}
$$

and vice versa

$$
\frac{d D}{d \pi}=\frac{\partial D}{\partial \pi}+\frac{\partial D}{\partial \alpha} \frac{d \alpha}{d \pi}
$$

\section{Scenario (1) (Expropriation)}

In this scenario, political risk is captured by the risk of expropriation. Recall that the investor's payoff function is given by

$$
\begin{aligned}
U_{1} & =\left(1-\pi_{1}\right) \int_{(1+r) D}^{\bar{R}} \alpha(1-t)[R-(1+r) D] \frac{1}{\bar{R}} d R-C(\alpha E) \\
& =\frac{\alpha(1-t)\left(1-\pi_{1}\right)}{\bar{R}}\left[\frac{1}{2} \bar{R}^{2}-(1+r) D \bar{R}+\frac{1}{2}(1+r)^{2} D^{2}\right]-C(\alpha E)
\end{aligned}
$$

and, as credits cannot be served when the project is expropriated, the break even 
condition is given by

$$
\begin{aligned}
\left(1-\pi_{1}\right)\left[\int_{(1+r) D}^{\bar{R}}(1+r) D \frac{1}{\bar{R}} d R+\int_{0}^{(1+r) D} s R \frac{1}{\bar{R}} d R\right] & =D \\
\frac{1-\pi_{1}}{\bar{R}}\left[(1+r) D \bar{R}-\frac{2-s}{2}(1+r)^{2} D^{2}\right] & =D
\end{aligned}
$$

Solving for $\frac{1}{2}(1+r)^{2} D^{2}$ and inserting into the payoff function yields the following payoff function to be maximized.

$$
U=\alpha(1-t)\left(1-\pi_{1}\right)\left[\frac{1}{2} \bar{R}-\frac{1-s}{2-s}(1+r) D\right]-\frac{\alpha(1-t)}{2-s} D-C(\alpha E)
$$

The following result describes how the investor chooses the optimal ownership share and the optimal debt level as a function of political risk.

Result 1 Consider an increase in political risk $\pi_{1}$ reflecting the risk of expropriation. Then the direct effect on the ownership share is negative and on debt it is zero. The total effects are both negative and smaller than the direct effects.

$$
\begin{aligned}
& \frac{d \alpha}{d \pi_{1}}<\frac{\partial \alpha}{\partial \pi_{1}}<0 \\
& \frac{d D}{d \pi_{1}}<\frac{\partial D}{\partial \pi_{1}}=0
\end{aligned}
$$

\section{Proof: See Appendix}

Not surprisingly, we find that the direct effect of political risk on the optimal ownership share is negative. As the risk of expropriation makes the investment less worthwhile, the investor is less interested in devoting costly equity to this project. ${ }^{4}$

The effects are less straightforward for debt. For any given interest rate, the fact that debt is expected to be served with smaller probability increases the incentive to use debt. However, since the banks need to break even, any decrease in the probability of debt

\footnotetext{
${ }^{4}$ This effect would be even more pronounced if the allocation of ownership rights can be used as a means to influence the likelihood of nationalization. As Konrad and Lommerud (2001) and Schnitzer (2002) have shown, it could be in the interest of the investor to share ownership with host country firms, even without compensation, if this makes the host country less prone to engage in expropriation or confiscatory taxation.
} 
repayment needs to be compensated by an adequate increase in interest rates. The overall direct effect on debt is therefore zero. Through the positive interaction with the optimal ownership share, the total effect on debt is negative, due to the negative response of the optimal ownership share.

Desai, Foley, and Hines Jr. (2006), who find empirically that debt is higher in high political risk countries, have argued that credits taken by local creditors may not react as much to political risk as local creditors may be more restricted in their choice of investment opportunities. The empirical evidence does however suggest that local interest rates react positively to political risk (Desai, Foley and Hines, 2004, Aggarwal and Kyaw (2004)).

\section{Scenario (2) Creeping expropriation}

In this scenario, political risk is captured by the reduction of expected returns. Recall that the investor's payoff function is given by

$$
\begin{aligned}
U_{2} & =\int_{(1+r) D}^{\left(1-\pi_{2}\right) \bar{R}} \alpha(1-t)[R-(1+r) D] \frac{1}{\left(1-\pi_{2}\right) \bar{R}} d R-C(\alpha E) \\
& =\frac{\alpha(1-t)}{\left(1-\pi_{2}\right) \bar{R}}\left[\frac{1}{2}\left(1-\pi_{2}\right)^{2} \bar{R}^{2}-(1+r) D\left(1-\pi_{2}\right) \bar{R}+\frac{1}{2}(1+r)^{2} D^{2}\right]-C(\alpha E)
\end{aligned}
$$

and the break even condition for banks is given by

$$
\begin{aligned}
\int_{(1+r) D}^{\left(1-\pi_{2}\right) \bar{R}}(1+r) D \frac{1}{\left(1-\pi_{1}\right) \bar{R}} d R+\int_{0}^{(1+r) D} s R \frac{1}{\left(1-\pi_{2}\right) \bar{R}} d R=D \\
\frac{1}{\left(1-\pi_{2}\right) \bar{R}}\left[(1+r) D\left(1-\pi_{2}\right) \bar{R}-\frac{2-s}{2}(1+r)^{2} D^{2}\right]=D
\end{aligned}
$$

Solving for $\frac{1}{2}(1+r)^{2} D^{2}$ and inserting into the payoff function yields the following payoff function to be maximized.

$$
U=\alpha(1-t)\left[\frac{1}{2}\left(1-\pi_{2}\right) \bar{R}-\frac{(1-s)(1+r)+1}{2-s} D\right]-C(\alpha E)
$$

The following result describes how the investor chooses the optimal ownership share and the optimal debt level as a function of political risk.

Result 2 Consider an increase in political risk $\pi_{2}$ reflecting the risk of diminished returns 
due to creeping expropriation. Then the direct effect on the ownership share and on debt are both negative. In both cases, the total effects are even more negative than the direct effects.

$$
\begin{aligned}
& \frac{d \alpha}{d \pi_{2}}<\frac{\partial \alpha}{\partial \pi_{2}}<0 \\
& \frac{d D}{d \pi_{2}}<\frac{\partial D}{\partial \pi_{2}}<0
\end{aligned}
$$

\section{Proof: See Appendix}

The effects on the optimal ownership share are very similar to the ones described in scenario 1. Also, like above, the political risk reduces the likelihood that credits can be served. In contrast to scenario 1 , however, political risk does not lead to outright but rather creeping expropriation. This increases the likelihood that credits are not served, but when this happens, banks can still use costly measures to secure part of the returns. It is this efficiency loss due to $s<1$ in case of bankruptcy that raises interest rates even more and hence drives a wedge between what the firm expects to give up in order to serve its debts and what the bank expects to receive. As a consequence the direct effect of political risk is to lower the optimal size of debt. Finally, as both direct effects are negative and the two effects reinforce each other, total effects are even more negative than direct effects.

\section{Scenario (3) Confiscatory taxation}

In this scenario, political risk reflects the risk of discriminating taxation or constraints on repatriating profits. In this case, the investor's payoff function is given by

$$
\begin{aligned}
U_{3} & =\int_{(1+r) D}^{\bar{R}} \alpha\left(1-t-\pi_{3}\right)[R-(1+r) D] \frac{1}{\bar{R}} d R-C(\alpha E) \\
& =\frac{\alpha\left(1-t-\pi_{3}\right)}{\bar{R}}\left[\frac{1}{2} \bar{R}^{2}-(1+r) D \bar{R}+\frac{1}{2}(1+r)^{2} D^{2}\right]-C(\alpha E)
\end{aligned}
$$

The break even condition for banks is not affected since political risk affects profits after credits are served. 
Thus

$$
\begin{aligned}
\int_{(1+r) D}^{\bar{R}}(1+r) D \frac{1}{\bar{R}} d R+\int_{0}^{(1+r) D} s R \frac{1}{\bar{R}} d R & =D \\
\frac{1}{\bar{R}}\left[(1+r) D \bar{R}-\frac{2-s}{2}(1+r)^{2} D^{2}\right] & =D
\end{aligned}
$$

Solving for $\frac{1}{2}(1+r)^{2} D^{2}$ and inserting into the payoff function yields the following payoff function to be maximized.

$$
U_{3}=\alpha\left(1-t-\pi_{3}\right)\left[\frac{1}{2} \bar{R}-\frac{(1-s)(1+r)+1}{2-s} D\right]-C(\alpha E)
$$

The following result describes how the investor chooses the optimal ownership share and the optimal debt level as a function of political risk.

Result 3 Consider an increase in political risk $\pi_{3}$ reflecting the risk of discriminating taxation or constraints on repatriating profits. Then the direct effect on ownership share is negative and the direct effect on debt is positive. The total effects on ownership and debt are ambiguous.

$$
\begin{gathered}
\frac{\partial \alpha}{\partial \pi_{3}}<0 \frac{d \alpha}{d \pi_{3}}>\text { or }<0 \\
\frac{\partial D}{\partial \pi_{3}}>0 \frac{d D}{d \pi_{3}}>\text { or }<0
\end{gathered}
$$

If the total effect on debt is positive, then the total effect on ownership is less negative than the direct effect on ownership, i.e.

$$
\text { if } \frac{d D}{d \pi_{3}}>0 \text { then } \frac{d \alpha}{d \pi_{3}}>\frac{\partial \alpha}{\partial \pi_{3}}<0
$$

\section{Proof: See Appendix}

Like before, political risk lowers the optimal ownership share. The effects on debt are now very different, however. In this case political risk lowers expected profits, but does not directly affect the expected debt repayment. This gives an incentive to shift from equity to debt financing, because whatever payment needs to be made to serve debt is not subject to discriminating taxation. Since the direct effects on ownership and on debt now have 
opposing signs, the total effects can be either positive or negative.

Note that this effect is equivalent to what we would expect in case of non-discriminating taxation t. Thus, we will include local tax rates as one of the control variables in our regressions.

We can summarize the findings from our theoretical analysis as follows: The direct effect of political risk on ownership share is negative in all three scenarios. Thus, unless the total effect of political risk on debt is positive and particularly strong, the total effect of political risk on ownership is always negative.

For the optimal debt level we find that the direct and total effects depend on the type of political risk. In scenario (1) and (2) the direct effects were either zero or negative. Thus, the total effect of political risk on debt has to be negative, due to the indirect effect via the ownership share. Only in scenario (3) did we find a positive direct effect of political risk on the optimal debt level. Here the total effect can be positive, provided the indirect effect via the ownership share is not too dominant.

We find further that the total effect of political risk on ownership share is less negative than the direct effect, if the total effect on debt is positive.

\section{$5 \quad$ Empirical predictions}

In our empirical analysis, we examine both the direct effects and the total effects of political risk on the financial structure of firms. We also investigate the relative strength of the direct and total effects. Furthermore, we study how the effects depend on the severity of the political risk, as captured by the different political risk scenarios. To isolate the direct effects we use the technique of instrumental variables. This is possible in case of the ownership share, but not in case of debt. Thus, we do not include predictions on the direct effects of political risk on the optimal debt level.

We now turn to the predictions that can be derived from our theoretical analysis. The first predictions are concerned with the optimal choice of ownership share. From Results 1-3 we derive the first hypothesis.

Hypothesis 1 The direct effect of political risk on the ownership share is negative for all types of political risk. 
In Results 1-3 we have also established the following for the total effects.

Hypothesis 2 The total effect of political risk on the ownership share is negative in Scenario (1) and (2) and ambiguous in Scenario (3). Thus, the less severe the political risk scenario, i.e. the more likely it is that Scenario (3) prevails, the less negative is the total effect of political risk on the ownership share.

This is due to the fact that only in Scenario (3) political risk can have a positive total effect on debt, which via the cross effect has a positive impact on the ownership share. This in turn should also be reflected by the relative size of the total and direct effects political risk has on the ownership share. The following hypothesis follows directly from Result 3.

Hypothesis 3 If the total effect of political risk on debt is positive the total effect of political risk on the ownership share is less negative than the direct effect.

The next hypotheses capture the impact of political risk on the the optimal debt level. As we have seen in Results 1-3, the total effects of political risk on the debt level can be negative and positive, depending on the type of political risk. This is captured by our next hypothesis.

Hypothesis 4 The total effect of political risk on the optimal debt level is negative in Scenarios 1 and 2 and ambiguous in Scenario 3. Thus, the total effect of political risk is less likely to be negative, the less severe the political risk scenario.

In the model, the optimal ownership share and the optimal debt level have positive cross effects on each other, as shown in Section 3. This was implicit in some of the predictions above, but is explicitly captured by the next prediction.

Hypothesis 5 The larger the debt level, the larger the ownership share.

Finally, we include one prediction about the impact of taxation on both the ownership share and the level of debt, based on Result 3. As we have seen, for a multinational firm the effects of non-discriminating taxation are equivalent to those of discriminating taxation. Hence the direct effects of taxation are unambiguously negative for the ownership share and positive for the debt level. The total effects are ambiguous. If the total effect on debt is positive, it mitigates the negative direct effect on the ownership share. The following hypothesis captures these effects. 
Hypothesis 6 The direct effect of taxation on the ownership share is negative. If the total effect on debt is positive, then the total effect of taxation on the ownership share is less negative than the direct effect.

\section{Data}

The empirical analysis presented in section 7 is based on the Microdatabase Direct Investment (MiDi) of the Deutsche Bundesbank. The database contains a panel dataset of firm-level information on German parents and their foreign affiliates for the years 1996 2003. The parents are by law required to report information on their investments and the financial characteristics of their foreign affiliates when the balance sheet total of the affiliate and the ownership share are larger than a certain threshold that varies over time (Lipponer 2006). We concentrate on directly held investment and use the strongest reporting requirements throughout our whole analysis.

We augment the MiDi dataset by country-level information. As a measure of political risk, we use the time-varying index that is provided by the International Country Risk Guide (ICRG). The index is made up from 12 weighted variables covering both political and social attributes. We recode the index in such a way that an increasing index represents higher political risk.

There are numerous indices that try to capture the quality of governance across countries. A good overview is provided by the World Bank (www.worldbank.org). For our analysis, the ICRG index is the best possible choice for three reasons: First, it takes into account many dimensions of political risk like corruption, bureaucratic quality, but also ethnic and religious tensions and socioeconomic conditions. Second, while many indicators only provide information on a selective sample of countries, the ICRG index has a very wide coverage with information on more than 140 countries. Third, ICRG index is not only time-varying, but provides information for all years that are covered in the MiDi dataset.

The source of information on GDP, GDP per capita and the rate of inflation is the Wold Economic Outlook Database of the IMF (http://www.imf.org). The Private Credit variable is based on Beck, Demirgc-Kunt, and Levine (1999). It measures the ratio of private credit lent by deposit money banks to GDP. Statutory tax rates are taken from the Institute for Fiscal Studies (http://www.ifs.org.uk), as well as from various issues of the Corporate Tax 
Guides of Ernst\&Young, KPMG and PricewaterhouseCoopers.

Table 1 provides descriptive statistics of the variables we use in our analysis. The definitions of the variables are standard, and they are also presented in Table 1.

\section{Econometric Analysis}

In our empirical analysis, we investigate how MNE react to variations in political risk. The two choice variables we consider are the ownership share and the level of leverage. The level of leverage is defined here as debt over total assets, the ownership share as the share of equity that the German parent holds in the foreign affiliate.

In all specifications we report below we include a set of controls that are standard in the literature on the capital structure choice of MNE and that we do not account for in our model. Throughout our analysis, the level of leverage and the ownership share are linear functions of the covariates. All regressions presented in this paper are estimated by OLS and include parent-fixed-effects to control for unobserved individual heterogeneity of the parents. We therefore compare differences in the capital structure of affiliates of the same parent in different countries. In all regressions, we use robust standard errors.

Empirically, the effects analyzed in a straightforward way are the total effects of the exogenous variables on the level of leverage and the ownership share. In Table 2, we present two separate regressions for the level of leverage and the ownership share. If leverage and ownership are not independent of each other, then leverage is an omitted variable in the ownership regression and vice versa. The reported coefficients therefore capture the sum of the direct effects of the covariates on the dependent variable and the indirect effect via the left-out variable. Thus, we can use these regressions to test our hypotheses on the total effects of political risk on the capital structure choice of MNE.

Our leverage regression presented in Table 2 confirms what Desai, Foley, and Hines Jr. (2004) find for US-American parents: affiliates of MNE are financed with a higher level of debt in countries with a higher level of political risk. This finding, however, is only consistent with our Scenario 3, political risk as confiscatory taxation, as specified in Hypothesis 4. The prevailing scenario for MNE today therefore seems to be one of least severe political risk.

For the ownership share, we find that the total effect of political risk is negative, as predicted in Hypothesis 2 for both Scenarios 1 and 2. However, a negative total effect of 
political risk is also consistent with Scenario 3, as long as the indirect positive effect via an increased level of leverage is smaller than the direct effect that is negative in all three scenarios.

Next, we want to analyze the direct effects of the covariates on the dependent variables and the relationship between leverage and ownership. To do this, we have to control for the level of leverage in the ownership regression. However, our theoretical model predicts that both leverage and ownership are determined endogenously. Therefore, simply including leverage in the ownership regression might yield biased results. To overcome this problem, we use the technique of two-step least squares. The share of retained profits over total assets acts as an instrument for the level of leverage in the ownership regression.

Table 3 presents the results of this instrumental variables regression. All coefficients in this table can be interpreted as the influence of the covariates on the ownership share when leverage is held constant, that is to say, as the direct effects of the covariates on ownership. First, we find that the direct effect of political risk on the ownership share is negative. This is consistent with our Hypothesis 1. We expect this relationship to hold for all types of political risk. Second, we can confirm our Hypothesis 5: There is a positive relationship between the level of leverage and the ownership share. Third, the direct effect of nondisciminatory statutory taxation on the ownership share is negative. This confirms the first part of Hypothesis 6 .

We now compare the total effects of the covariates on the ownership share (Table 2) to the direct effects (Table 3). The difference between total effects and direct effects is caused by the indirect effects via a change in the level of leverage. Therefore, the relationship between total and direct effects depends on the direction of change that political risk causes in the level of leverage. We have found that the total effect of political risk on the level of leverage is positive. Thus, we expect that the total effect of political risk on the ownership share is less negative than the direct effect (Hypothesis 3). By comparing the coefficients in Table 2 and Table 3, we can confirm this hypothesis. We further expect the total effect of taxation on the ownership share to be less negative than the direct effect (Hypothesis 6 ). Again, this hypothesis can be confirmed empirically.

To sum up, when we consider the average of all German MNEs, we find, first, that the direct effect of political risk on the ownership share is negative, and that there is a positive relationship between the level of leverage and the ownership share. This is what 
we expect for alle types of political risk. Second, we find that the total effect of political risk on the level of leverage is positive, while political risk has a negative total effect on the ownership share. Thus, the type of political risk that seems to prevail for the aggregate of MNE is the least severe form (Scenario 3). For the aggregate of MNE, the predictions of our model regarding the direct and indirect effects of political risk and taxation on the capital structure of MNE are consistent with our theoretical predictions when political risk acts as confiscatory taxation.

In the remainder of the analysis, we attempt to capture the effects of different types of political risk. Ideally, we would like to capture this directly by using a time-varying country-specific indicator measuring each scenario of political risk separately. These indices should be comparable in their coverage of countries and time and ideally even the methodology used. There are some indicators measuring certain dimensions of political risk like the Corruption Perceptions Index by Transparency International or the Heritage Index. However, most of the indices do not cover the countries and time periods in our dataset sufficiently (as it is the case with the Transparency International Index). The main problem is that there are no three indices that act as proxy for each of the three political risk scenarios seperately, while not being related to the other scenarios. So, capturing the effects of different types of political risk directly is not a feasible option.

We therefore attempt to capture the effect of different types of political risk in an indirect way. One possibility to do this it to divide the dataset at the median of political risk. Table 4 and 5 show our regressions for enterprises that face a level of risk below the median, Table 6 and 7 for those enterprises facing a higher than average political risk.

When we compare the influence that political risk has on the capital structure in high and low risk countries, our findings are the following: First, we find that the influence of political risk on the level of leverage is more than twice as large when political risk is low than when it is high. This is consistent with our Hypothesis 4: In countries with less severe political risk (Scenario 3), we expect the influence of political risk on the level of leverage to be more positive than otherwise (Scenarios 1 and 2).

Second, we find that the influence of political risk on the ownership share is less significant when political risk is is low as compared to when political risk is high. This is consistent with our Hypothesis 2. The less severe is political risk (Scenario 3), the less negative is its effect on the ownership share. 
A second way to capture different types of political risk is by analyzing its interaction with GDP per capita. In countries where GDP per capita is high we expect political risk to act in its less severe form while in countries where GDP is low we expect that the consequences of political risk on MNE are more severe.

In Table 8 and 9 we report the effects of political risk on leverage and ownership, containing an interaction term between GDP per capita and political risk. While the effect of both GDP per capita and statutory taxes on the level of leverage remain positive, there is a drastic change in the coefficient of political risk in the leverage regression. This coefficient is now negative and significant, while the coefficient of the interaction term between GDP per capita and political risk is positive and significant.

Therefore, we find that the way MNE adapt their level of leverage in response to political risk depends on GDP per capita. In countries where GDP per capita is low and we therefore expect political risk to be severe, MNE lower their level of leverage in response to political risk. In countries with higher GDP and less severe consequences of political risk, we find that MNE finance their affiliates with a higher level of debt when political risk increases. These findings again support our Hypothesis 4: the total effect of political risk is less likely to be negative, the less severe the political risk scenario.

For the ownership share, we find that the coefficient of political risk remains negative when the interaction term between political risk and GDP per capita is included. The interaction term, however, has a positive and significant coefficient. Therefore, in countries where GDP per capita is high, the influence of political risk on the ownership share is less negative than when political risk is low. This supports our Hypothesis 2: The less severe the political risk scenario, the less negative is the total effect on political risk. These findings show that the the response of MNE to political risk is not at all homogenous, but it strongly depends on the type of political risk present.

\section{Conclusion}

In this paper, we have investigated both theoretically and empirically how MNEs adapt their capital structure choices in the presence of political risk. Not surprisingly, political risk in general is bad for the profitability of a MNE as a whole. However, as our analysis has shown, different types of political risk may have very different economic effects for different 
stakeholders of the firm. Of course, equity holders as the residual claimants always suffer from political risk and therefore want to reduce their exposure by limiting their ownership share. Debt holders, in contrast, need not be affected in the same way. As a consequence, the impact of political risk on debt financing may differ from that on equity financing. This is why the effect of political risk on the optimal leverage turns out to be different for different types of political risk.

Our analysis suggests that when it comes to assessing the potential effects of political risk, it is important to distinguish different types of stakeholders and how they are affected by different political measures. Only then is it possible to determine the optimal reaction of the investor to this risky environment.

Another insight from our analysis is that the choices of ownership share and leverage are interdependent and hence total effects of political risk may substantially differ from direct effects. In particular, if leverage and ownership ratio are positively related, as observed, then the total effects are smaller than direct effects. Thus, if one of the two choice variables is not available, due to political restrictions on ownership shares or capital requirements, the investor will react more strongly with the remaining choice variable. Suppose for example that a government imposes a minimum capital rule to enforce more equity financing. Then this will make the multinational investor limit his exposure by choosing an even smaller ownership share. Governments need to be aware of this interaction when designing their rules on multinational investments. 


\section{Mathematical Appendix}

\section{Solution of the base line model}

The investor's maximization problem is characterized by the following two first order conditions.

$$
\begin{aligned}
& \frac{d U}{d \alpha}=(1-t)\left[\frac{1}{2} \bar{R}-\frac{(1-s)(1+r)+1}{2-s} D\right]-(I-D) C^{\prime}=0 \\
& \frac{d U}{d D}=-\frac{\alpha(1-t)}{(2-s)}\left[(1-s)(1+r)+1+(1-s) \frac{d r}{d D} D\right]+\alpha C^{\prime}=0
\end{aligned}
$$

From the first order conditions we derive further

$$
\begin{aligned}
\frac{d^{2} U}{d \alpha^{2}} & =-(I-D)^{2} C^{\prime \prime}<0 \\
\frac{d^{2} U}{d \alpha d D}=\frac{d^{2} U}{d D d \alpha} & =\underbrace{-\frac{1-t}{2-s}\left[(1-s)(1+r)+1+(1-s) \frac{d r}{d D} D\right]+C^{\prime}}_{=0}+(I-D) \alpha C^{\prime \prime} \\
& =(I-D) \alpha C^{\prime \prime}>0 \quad \alpha(1-t)(1-s) \\
\frac{d^{2} U}{d D^{2}} & \left.=-\alpha^{2} C^{\prime \prime}-\frac{\alpha(1 r}{d D}+\frac{d^{2} r}{d D^{2}} D\right)<0
\end{aligned}
$$

This gives us the following matrix

$$
F=\left|\begin{array}{cc}
-(I-D)^{2} C^{\prime \prime} & (I-D) \alpha C^{\prime \prime} \\
(I-D) \alpha C^{\prime \prime} & -\left[\alpha^{2} C^{\prime \prime}+\frac{\alpha(1-t)(1-s)}{2-s}\left(2 \frac{d r}{d D}+\frac{d^{2} r}{d D^{2}} D\right)\right]
\end{array}\right|
$$

It is straightforward to show that

$$
|F|=(I-D)^{2} C^{\prime \prime} \frac{\alpha(1-t)(1-s)}{2-s}\left(2 \frac{d r}{d D}+\frac{d^{2} r}{d D^{2}} D\right)>0
$$

so that the first order conditions describe a maximum.

\section{Proof of Result 1}

The investor's maximization problem is now characterized by the following two first order conditions.

$$
\begin{aligned}
& \frac{d U}{d \alpha}=(1-t)\left(1-\pi_{1}\right)\left[\frac{1}{2} \bar{R}-\frac{(1-s)(1+r)}{2-s} D\right]-\frac{1-t}{2-s} D-(I-D) C^{\prime}=0 \\
& \frac{d U}{d D}=-\frac{\alpha(1-t)\left(1-\pi_{1}\right)(1-s)}{(2-s)}\left[(1+r)+\frac{d r}{d D} D\right]-\frac{\alpha(1-t)}{2-s}+\alpha C^{\prime}=0
\end{aligned}
$$


From the first order conditions we derive further

$$
\begin{aligned}
\frac{d^{2} U}{d \alpha^{2}} & =-(I-D)^{2} C^{\prime \prime}<0 \\
\frac{d^{2} U}{d \alpha d D}=\frac{d^{2} U}{d D d \alpha} & =\underbrace{-\frac{(1-t)\left(1-\pi_{1}\right)(1-s)}{2-s}\left[(1+r)+\frac{d r}{d D} D\right]-\frac{1-t}{2-s}+C^{\prime}}_{=0}+(I-D) \alpha C^{\prime \prime} \\
& =(I-D) \alpha C^{\prime \prime}>0 \\
\frac{d^{2} U}{d D^{2}} & =-\alpha^{2} C^{\prime \prime}-\frac{\alpha(1-t)(1-s)\left(1-\pi_{1}\right)}{2-s}\left(2 \frac{d r}{d D}+\frac{d^{2} r}{d D^{2}} D\right)-\frac{\alpha(1-t)}{2-s}<(044)
\end{aligned}
$$

This gives us the following matrix

$$
F=\left|\begin{array}{cc}
-(I-D)^{2} C^{\prime \prime} & (I-D) \alpha C^{\prime \prime} \\
(I-D) \alpha C^{\prime \prime} & -\left[\alpha^{2} C^{\prime \prime}+\frac{\alpha(1-t)(1-s)\left(1-\pi_{1}\right)}{2-s}\left(2 \frac{d r}{d D}+\frac{d^{2} r}{d D^{2}} D\right)+\frac{\alpha(1-t)}{2-s}\right]
\end{array}\right|
$$

It is straightforward to show that

$$
|F|=(I-D)^{2} C^{\prime \prime} \frac{\alpha(1-t)}{2-s}\left[\left(1-\pi_{1}\right)(1-s)\left(2 \frac{d r}{d D}+\frac{d^{2} r}{d D^{2}} D\right)+1\right]>0
$$

so that the first order conditions describe a maximum.

For our comparative statics analysis we need to determine

$$
\frac{d^{2} U}{d \alpha d \pi_{1}}=-\left[\frac{1}{2} \bar{R}-\frac{1-s}{2-s}(1+r) D\right]<0
$$

and

$$
\frac{d^{2} U}{d D d \pi_{1}}=\frac{\alpha(1-t)(1-s)}{2-s}\left[1+r+\frac{d r}{d D} D\right]-\frac{\alpha(1-t)\left(1-\pi_{1}\right)(1-s)}{2-s}\left[\frac{d r}{d \pi_{1}}+\frac{d^{2} r}{d D d \pi_{1}} D\right]
$$

Recall that $r$ is implicitly determined by

$$
\left(1-\pi_{1}\right)(1+r)-\frac{2-s}{2} \frac{1-\pi_{1}}{\bar{R}}(1+r)^{2} D-1=0
$$

Using the implicit function theorem we can derive from this

$$
\frac{d r}{d D}=-\frac{-\frac{2-s}{2} \frac{1-\pi_{1}}{\bar{R}}(1+r)^{2}}{\left(1-\pi_{1}\right)-(2-s) \frac{1-\pi_{1}}{\bar{R}}(1+r) D}
$$




$$
\begin{aligned}
& =\frac{(2-s)(1+r)^{2}}{2[\bar{R}-(2-s)(1+r) D]}>0 \\
\frac{d^{2} r}{d D d \pi_{1}} & =0 \\
\frac{d r}{d \pi_{1}} & =-\frac{-(1+r)+\frac{2-s}{2} \frac{1}{R}(1+r)^{2} D}{\left(1-\pi_{1}\right)-(2-s) \frac{1-\pi_{1}}{\bar{R}}(1+r) D} \\
& =\frac{(1+r)[2 \bar{R}-(2-s)(1+r) D]}{2\left(1-\pi_{1}\right)[\bar{R}-(2-s)(1+r) D]}>0 \\
\frac{d^{2} r}{d \pi_{1}^{2}} & >0
\end{aligned}
$$

Using these, we find that

$$
\begin{aligned}
\frac{d^{2} U}{d D d \pi_{1}}= & \frac{\alpha(1-t)(1-s)}{2-s} \\
& {\left[1+r+\frac{(2-s)(1+r)^{2} D}{2[\bar{R}-(2-s)(1+r) D]}-\frac{(1+r)[2 \bar{R}-(2-s)(1+r) D]}{2[\bar{R}-(2-s)(1+r) D}\right] } \\
= & \frac{\alpha(1-t)(1-s)}{2-s}[0]=0
\end{aligned}
$$

Thus, using the implicit function theorem it is straightforward to derive the direct effects of $\pi_{1}$ on $\alpha$ and $D$ are

$$
\begin{aligned}
\frac{\partial \alpha}{\partial \pi_{1}} & =-\frac{\frac{d^{2} U}{d \alpha d \pi_{1}}}{\frac{d^{2} U}{d \alpha^{2}}}=-\frac{-\left[\frac{1}{2} \bar{R}-\frac{1-s}{2-s}(1+r) D\right]}{-(I-D)^{2} C^{\prime \prime}}<0 \\
\frac{\partial D}{\partial \pi_{1}} & =-\frac{\frac{d^{2} U}{d D d \pi_{1}}}{\frac{d^{2} U}{d D^{2}}}=-\frac{0}{-\left[\alpha C^{\prime \prime}+\frac{\alpha(1-t)}{2-s}\left(\left(1-\pi_{1}\right)(1-s)\left[\frac{2 d r}{d D}+\frac{d^{2} r}{d D^{2}} D\right]+1\right)\right]}=0
\end{aligned}
$$

To determine the total effects, we use the following matrixes

$$
F_{\alpha \pi_{1}}=\left|\begin{array}{cc}
\frac{1}{2} \bar{R}-\frac{1-s}{2-s}(1+r) D & (I-D) \alpha C^{\prime \prime} \\
0 & -\left[\alpha^{2} C^{\prime \prime}+\frac{\alpha(1-t)}{2-s}\left(\left(1-\pi_{1}\right)(1-s)\left[2 \frac{d r}{d D}+\frac{d^{2} r}{d D^{2}} D\right]+1\right)\right]
\end{array}\right|
$$

and 


$$
F_{D \pi_{1}}=\left|\begin{array}{cc}
-(I-D)^{2} C^{\prime \prime} & \frac{1}{2} \bar{R}-\frac{1-s}{2-s}(1+r) D \\
(I-D) \alpha C^{\prime \prime} & 0
\end{array}\right|
$$

Using these we can determine the total effects as follows

$$
\begin{aligned}
\frac{d \alpha}{d \pi_{1}}= & \frac{\left|F_{\alpha \pi_{1}}\right|}{|F|}=-\frac{1}{|F|}\left[\frac{1}{2} \bar{R}-\frac{1-s}{2-s}(1+r) D\right] \\
& {\left[\alpha C^{\prime \prime}+\frac{\alpha(1-t)}{2-s}\left(\left(1-\pi_{1}\right)(1-s)\left[2 \frac{d r}{d D}+\frac{d^{2} r}{d D^{2}} D\right]+1\right)\right]<0 } \\
\frac{d D}{d \pi_{1}}= & \frac{\left|F_{D \pi_{1}}\right|}{|F|}=-\frac{1}{|F|} \alpha(I-D) C^{\prime \prime}\left[\frac{1}{2} \bar{R}-\frac{1-s}{2-s}(1+r) D\right]<0
\end{aligned}
$$

which lead to the results presented in Result 1.

Note further that

$$
\begin{aligned}
\frac{\partial \alpha}{\partial \pi_{1}}= & -\frac{-\left[\frac{1}{2} \bar{R}-\frac{1-s}{2-s}(1+r) D\right]}{-(I-D)^{2} C^{\prime \prime}} \\
>\frac{d \alpha}{d \pi_{1}}= & -\frac{1}{|F|}\left[\frac{1}{2} \bar{R}-\frac{1-s}{2-s}(1+r) D\right] \\
& {\left[\alpha^{2} C^{\prime \prime}+\frac{\alpha(1-t)}{2-s}\left(\left(1-\pi_{1}\right)(1-s)\left[2 \frac{d r}{d D}+\frac{d^{2} r}{d D^{2}} D\right]+1\right)\right] }
\end{aligned}
$$

Q.E.D

\section{Proof of Result 2}

The investor's maximization problem is now characterized by the following two first order conditions.

$$
\begin{aligned}
& \frac{d U}{d \alpha}=(1-t)\left[\frac{1}{2}\left(1-\pi_{2}\right) \bar{R}-\frac{[(1-s)(1+r)+1]}{2-s} D\right]-(I-D) C^{\prime}=0 \\
& \frac{d U}{d D}=-\frac{\alpha(1-t)(1-s)}{(2-s)}\left[(1+r)+\frac{d r}{d D} D\right]-\frac{\alpha(1-t)}{2-s}+\alpha C^{\prime}=0
\end{aligned}
$$

From the first order conditions we derive further

$$
\frac{d^{2} U}{d \alpha^{2}}=-(I-D)^{2} C^{\prime \prime}<0
$$




$$
\begin{aligned}
\frac{d^{2} U}{d \alpha d D}=\frac{d^{2} U}{d D d \alpha} & =\underbrace{-\frac{(1-t)(1-s)}{2-s}\left[(1+r)+\frac{d r}{d D} D\right]-\frac{1-t}{2-s}+C^{\prime}}_{=0}+(I-D) \alpha C^{\prime \prime} \\
& =(I-D) \alpha C^{\prime \prime}>0 \\
\frac{d^{2} U}{d D^{2}} & =-\alpha^{2} C^{\prime \prime}-\frac{\alpha(1-t)(1-s)}{2-s}\left(2 \frac{d r}{d D}+\frac{d^{2} r}{d D^{2}} D\right)<0
\end{aligned}
$$

This gives us the following matrix

$$
F=\left|\begin{array}{cc}
-(I-D)^{2} C^{\prime \prime} & (I-D) \alpha C^{\prime \prime} \\
(I-D) \alpha C^{\prime \prime} & -\left[\alpha^{2} C^{\prime \prime}+\frac{\alpha(1-t)(1-s)}{2-s}\left(2 \frac{d r}{d D}+\frac{d^{2} r}{d D^{2}} D\right)\right.
\end{array}\right|
$$

It is straightforward to show that

$$
|F|=(I-D)^{2} C^{\prime \prime} \frac{\alpha(1-t)}{2-s}\left[(1-s)\left(2 \frac{d r}{d D}+\frac{d^{2} r}{d D^{2}} D\right)+1\right]>0
$$

so that the first order conditions describe a maximum.

We first determine

$$
\frac{d^{2} U}{d \alpha d \pi_{2}}=-(1-t) \frac{1}{2} \bar{R}<0
$$

and

$$
\frac{d^{2} U}{d D d \pi_{2}}=-\frac{\alpha(1-t)(1-s)}{2-s}\left[\frac{d r}{d \pi_{2}}+\frac{d^{2} r}{d D d \pi_{2}} D\right]<0
$$

To see this recall that $r$ is implicitly determined by

$$
(1+r)-\frac{2-s}{2\left(1-\pi_{2}\right)} \frac{(1+r)^{2} D}{\bar{R}}-1=0
$$

Using the implicit function theorem we can derive from this

$$
\begin{aligned}
\frac{d r}{d D} & =-\frac{-\frac{2-s}{2\left(1-\pi_{2}\right)} \frac{(1+r)^{2}}{\bar{R}}}{1-\frac{(2-s)(1+r) D}{\left(1-\pi_{2}\right) \bar{R}}} \\
& =\frac{(2-s)(1+r)^{2}}{2\left[\left(1-\pi_{2}\right) \bar{R}-(2-s)(1+r) D\right]}>0 \\
\frac{d^{2} r}{d D d \pi_{2}} & >0
\end{aligned}
$$




$$
\begin{aligned}
\frac{d r}{d \pi_{2}} & =-\frac{-\frac{(2-s)(1+r)^{2} D}{2} \frac{1}{\left(1-\pi_{2}\right)^{2} \bar{R}}}{1-\frac{(2-s)(1+r) D}{\left(1-\pi_{2}\right) \bar{R}}} \\
& =\frac{(1+r)^{2}(2-s) \bar{R}}{2\left[\left(1-\pi_{2}\right) \bar{R}-(2-s)(1+r) D\right]^{2}}>0 \\
\frac{d^{2} r}{d \pi_{2}{ }^{2}} & >0
\end{aligned}
$$

Thus, using the implicit function theorem it is straightforward to derive the direct effects of $\pi_{2}$ on $\alpha$ and $D$, as done in Result 2 .

Furthermore, we can determine the following matrixes

$$
F_{\alpha \pi_{2}}=\left|\begin{array}{cc}
(1-t) \frac{1}{2} \bar{R} & (I-D) \alpha C^{\prime \prime} \\
\frac{\alpha(1-t)(1-s)}{2-s}\left[\frac{d r}{d \pi_{2}}+\frac{d^{2} r}{d D d \pi_{2}} D\right] & -\left[\alpha^{2} C^{\prime \prime}+\frac{\alpha(1-t)(1-s)}{2-s}\left[2 \frac{d r}{d D}+\frac{d^{2} r}{d D^{2}} D\right]\right]
\end{array}\right|
$$

and

$$
F_{D \pi_{2}}=\left|\begin{array}{cc}
-(I-D)^{2} C^{\prime \prime} & (1-t) \frac{1}{2} \bar{R} \\
(I-D) \alpha C^{\prime \prime} & \frac{\alpha(1-t)(1-s)}{2-s}\left[\frac{d r}{d \pi_{2}}+\frac{d^{2} r}{d D d \pi_{2}} D\right]
\end{array}\right|
$$

which lead to the results presented in Result 2.

$$
\begin{aligned}
\frac{\partial \alpha}{\partial \pi_{2}}= & -\frac{\frac{d^{2} U}{d \alpha d \pi_{2}}}{\frac{d^{2} U}{d \alpha^{2}}}=-\frac{-(1-t) \frac{1}{2} \bar{R}}{-(I-D)^{2} C^{\prime \prime}}<0 \\
\frac{d \alpha}{d \pi_{2}}= & \frac{\left|F_{\alpha \pi_{2}}\right|}{|F|}=-\frac{1}{|F|}\left[(1-t) \frac{1}{2} \bar{R}\left[-\left(\alpha^{2} C^{\prime \prime}+\frac{\alpha(1-t)}{2-s}\left[2 \frac{d r}{d D}(1-s)+\frac{d^{2} r}{d D^{2}}(1-s) D\right]\right)\right]\right. \\
& \left.+(I-D) C^{\prime \prime} \frac{\alpha(1-t)}{2-s}\left[\frac{d r}{d \pi_{2}}(1-s)+\frac{d^{2} r}{d D d \pi_{2}}(1-s) D\right]\right] \\
& <\frac{\partial \alpha}{\partial \pi_{2}}<0 \\
\frac{\partial D}{\partial \pi_{2}}= & -\frac{\frac{d^{2} U}{d D d \pi_{2}}}{\frac{d^{2} U}{d D^{2}}}=-\frac{-\frac{\alpha(1-t)}{2-s}\left[\frac{d r}{d \pi_{2}}(1-s)+\frac{d^{2} r}{d D d \pi_{2}}(1-s) D\right]}{\left.2-s C^{\prime \prime}+\frac{\alpha(1-t)}{2-s}\left[2 \frac{d r}{d D}(1-s)+\frac{d^{2} r}{d D^{2}}(1-s) D\right]\right]}<0 \\
\frac{d D}{d \pi_{2}}= & \frac{\left|F_{D \pi_{2}}\right|}{|F|}=-\frac{1}{|F|}\left[(I-D)^{2} C^{\prime \prime} \frac{\alpha(1-t)}{2-s}\left[\frac{d r}{d \pi_{2}}(1-s)+\frac{d^{2} r}{d D d \pi_{2}}(1-s) D\right]\right.
\end{aligned}
$$




$$
\left.+(1-t) \frac{1}{2} \bar{R}(I-D) \alpha C^{\prime \prime}\right]<\frac{\partial D}{\partial \pi_{2}}<0
$$

Q.E.D.

Proof of Result 3 The investor's maximization problem is now characterized by the following two first order conditions.

$$
\begin{aligned}
& \frac{d U}{d \alpha}=\left(1-t-\pi_{3}\right)\left[\frac{1}{2} \bar{R}-\frac{(1-s)(1+r)+1}{2-s} D\right]-(I-D) C^{\prime}=0 \\
& \frac{d U}{d D}=-\frac{\alpha\left(1-t-\pi_{3}\right)(1-s)}{(2-s)}\left[(1+r)+\frac{d r}{d D} D\right]-\frac{\alpha\left(1-t-\pi_{3}\right)}{2-s}+\alpha C^{\prime}=0
\end{aligned}
$$

From the first order conditions we derive further

$$
\begin{aligned}
\frac{d^{2} U}{d \alpha^{2}} & =-(I-D)^{2} C^{\prime \prime}<0 \\
\frac{d^{2} U}{d \alpha d D}=\frac{d^{2} U}{d D d \alpha} & =\underbrace{-\frac{\left(1-t-\pi_{3}\right)(1-s)}{2-s}\left[(1+r)+\frac{d r}{d D} D\right]-\frac{1-t-\pi_{3}}{2-s}+C^{\prime}}_{=0}+(I-D) \alpha C^{\prime \prime} \\
& =(I-D) \alpha C^{\prime \prime}>0 \\
\frac{d^{2} U}{d D^{2}} & =-\alpha^{2} C^{\prime \prime}-\frac{\alpha\left(1-t-\pi_{3}\right)(1-s)}{2-s}\left(2 \frac{d r}{d D}+\frac{d^{2} r}{d D^{2}} D\right)-\frac{\alpha\left(1-t-\pi_{3}\right)}{2-s}<(\text { (78) }
\end{aligned}
$$

This gives us the following matrix

$$
F=\left|\begin{array}{cc}
-(I-D)^{2} C^{\prime \prime} & (I-D) \alpha C^{\prime \prime} \\
(I-D) \alpha C^{\prime \prime} & -\left[\alpha^{2} C^{\prime \prime}+\frac{\alpha\left(1-t-\pi_{3}\right)(1-s)}{2-s}\left(2 \frac{d r}{d D}+\frac{d^{2} r}{d D^{2}} D\right)\right]
\end{array}\right|
$$

It is straightforward to show that

$$
|F|=(I-D)^{2} C^{\prime \prime} \frac{\alpha\left(1-t-\pi_{3}\right)(1-s)}{2-s}\left[2 \frac{d r}{d D}+\frac{d^{2} r}{d D^{2}} D\right]>0
$$

so that the first order conditions describe a maximum.

We first determine

$$
\frac{d^{2} U}{d \alpha d \pi_{3}}=-\left[\frac{1}{2} \bar{R}-\frac{1-s}{2-s}(1+r) D\right]<0
$$

and

$$
\frac{d^{2} U}{d D d \pi_{3}}=\frac{\alpha}{2-s}\left[(1-s)(1+r)+1+(1-s) \frac{d r}{d D} D\right]>0
$$


Thus, using the implicit function theorem it is straightforward to derive the direct effects of $\pi_{3}$ on $\alpha$ and $D$, as done in Result 1 .

Furthermore, we can determine the following matrixes

$$
F_{\alpha \pi_{3}}=\left|\begin{array}{cc}
\frac{1}{2} \bar{R}-\frac{(1-s)(1+r)+1}{2-s} D & (I-D) \alpha C^{\prime \prime} \\
-\frac{\alpha}{2-s}\left[(1-s)(1+r)+1+(1-s) \frac{d r}{d D} D\right] & -\left[\alpha^{2} C^{\prime \prime}+\frac{\alpha\left(1-t-\pi_{3}\right)(1-s)}{2-s}\left(2 \frac{d r}{d D}+\frac{d^{2} r}{d D^{2}} D\right)\right]
\end{array}\right|
$$

and

$$
F_{D \pi_{3}}=\left|\begin{array}{cc}
-(I-D)^{2} C^{\prime \prime} & \frac{1}{2} \bar{R}-\frac{(1-s)(1+r)+1}{2-s} D \\
(I-D) \alpha C^{\prime \prime} & -\frac{\alpha}{2-s}\left[(1-s)(1+r)+1+(1-s) \frac{d r}{d D} D\right]
\end{array}\right|
$$

which lead to the results presented in Result 3.

$$
\begin{aligned}
\frac{\partial \alpha}{\partial \pi_{3}}= & -\frac{\frac{d^{2} U}{d \alpha d \pi_{3}}}{\frac{d^{2} U}{d \alpha^{2}}}=-\frac{-\left[\frac{1}{2} \bar{R}-\frac{(1-s)(1+r)+1}{2-s} D\right]}{-(I-D)^{2} C^{\prime \prime}}<0 \\
\frac{d \alpha}{d \pi_{3}}= & \frac{\left|F_{\alpha \pi_{3}}\right|}{|F|}= \\
& \frac{1}{|F|}\left[-\left[\frac{1}{2} \bar{R}-\frac{(1-s)(1-r)+1}{2-s} D\right]\left[\alpha^{2} C^{\prime \prime}+\frac{\alpha\left(1-t-\pi_{3}\right)(1-s)}{2-s}\left(2 \frac{d r}{d D}+\frac{d^{2} r}{d D^{2}} D\right)\right]\right. \\
& \left.+(I-D) C^{\prime \prime} \frac{\alpha^{2}}{2-s}\left[(1-s)(1+r)+1+(1-s) \frac{d r}{d D} D\right]\right]>\text { or }<0 \\
\frac{\partial D}{\partial \pi_{3}}= & -\frac{\frac{d^{2} U}{d D d_{3}}}{\frac{d^{2} U}{d D^{2}}}=-\frac{\frac{\alpha}{2-s}\left[(1-s)(1+r)+1+(1-s) \frac{d r}{d D} D\right]}{-\frac{\alpha\left(1-t-\pi_{3}\right)}{2-s}\left[2(1-s) \frac{d r}{d D}+(1-s) \frac{d^{2} r}{d D^{2}} D\right]}>0 \\
\frac{d D}{d \pi_{3}}= & \frac{\left|F_{D \pi_{3}}\right|}{|F|}=-\frac{1}{|F|}(I-D) \alpha C^{\prime \prime}\left[\frac{1-s}{2-s}\left[(I-D) \frac{d r}{d D} D+r I\right]-\left(\frac{1}{2} \bar{R}-I\right)\right]>\text { or }<0
\end{aligned}
$$

Finally note that

$$
\frac{d \alpha}{d \pi_{3}}=\frac{\partial \alpha}{\partial \pi_{3}}+\frac{\partial \alpha}{\partial D} \frac{d D}{\pi_{3}}>\frac{\partial \alpha}{\partial \pi_{3}}
$$

if $\frac{d D}{d \pi_{3}}>0$ as

$$
\frac{d \alpha}{d D}=-\frac{\frac{d^{2} U}{d \alpha d D}}{\frac{d^{2} U}{d \alpha^{2}}}>0
$$




\section{References}

Aggarwal, R., And N. A. Kyaw (2004): "Internal Capital Markets and Capital Structure Choice of U.S. Multinationals' Affiliates," mimeo.

Andersson, T. (1991): Multinational Investment in Developing Countries: A Study of Taxation and Nationalization. Routledge, London and New York.

Asiedu, E., AND H. Esfahani (2001): "Ownership structure in foreign direct investment projects," Review of Economics and Statistics, 83, 647-662.

Beck, T., A. Demirgc-Kunt, and R. Levine (1999): A New Database on Financial Development Structure. Policy Research Working Paper No. 2146, Washington DC: World Bank.

Buckley, A. (1992): Multinational Finance. Prentice Hall, International, 2 edn.

Buettner, T., M. Overesch, U. Schreiber, and G. Wamser (2006): "Taxation and Capital Structure Choice- Evidence from a Panel of German Multinationals," Discussion paper, CESIfo Working Paper No. 1841.

Desai, M. A., C. F. Foley, And J. R. Hines JR. (2004): "A multinational perspective on capital structure choice and internal capital markets," The Journal of Finance, 59, $2451-2487$.

— (2006): Capital Structure with Risky Foreign Investment. mimeo.

Eaton, J., G. M. (1995): "Sovereign Debt," in Handbook of International Economics, ed. by G. G.M., and K. Rogoff, pp. 2031-2077. North Holland, Amsterdam.

Eaton, J., And M. Gersovitz (1983): "Country risk: economic aspects," in Managing International Risk, ed. by R. J. Herring, pp. 75-108. Cambridge University Press, Cambridge, UK.

ERnst\&Young (Various Issues.): Worldwide Corporate Tax Guide.

Froot, K. A., D. S. Scharfstein, And J. C. Stein (1993): "Risk Management: Coordinating Corporate Investment and Financing Policies," The Journal of Finance, 48, $1629-1658$. 
Hill, C. A. (1998): "How Investors Reacto to Political Risk," Duke Journal of Comparative and International Law, 8, No 2.

Huizinga, H. P., L. Laeven, And G. Nicodeme (2006): "Capital Structure Choice and International Debt Shifting," Discussion paper, CEPR Discussion Paper No. 5882.

JANEBA, E. (2000): "Tax competition when government lack commitment: excess capacity as a countervailing threat," American Economic Review, 90, 1508-1519.

KobRin, S. J. (1980): "Foreign enterprise and forced divestment in LDCs," International Organization, 41, 609-638.

Konrad, K., And K. Lommerud (2001): "Foreign direct investment, intra-firm trade and ownership structure," European Economic Review, 45, 475-494.

KPMG (Various Issues): KPMG's Corporate Tax Rate Survey.

Lipponer, A. (2006): Microdatabase Direct Investment- MiDi. A Brief Guide. Bundesbank Working Paper, Frankfurt.

Mueller, T., AND M. Schnitzer (2006): "Technology transfer and spillovers in international joint ventures," Journal of International Economics, 68(2), 456-468.

Novaes, W., And S. Werlang (2005): "Political Risk and Capital Structure Choice of Foreign Subsidiaries: An Empirical Analysis," mimeo.

PricewaterhouseCoopers (????): Corporate Taxes. Worldwide Summary.

Schnitzer, M. (1999): "Expropriation and control rights: a dynamic model of foreign direct investment," International Journal of Industrial Organization, 17, 1113-37.

Stein, J. C. (1998): "An Adverse-Selection Model of Bank Asset and Liability Management with Implications for Transmission of Monetary Policy," RAND Journal of Economics, 29(3), 466-486.

- (2003): "Agency, Information and Corporate Investment," in Handbook of the Economics of Finance, ed. by G. Constantinides, M. Harris, and R. Stulz. North Holland, Amsterdam. 
Thomas, J., And T. Worrall (1994): "Foreign direct investment and the risk of expropriation," Review of Economic Studies, 61, 81-108. 
Table 1

Descriptive Statistics

\begin{tabular}{llrrrr} 
& Definition & Mean & \multicolumn{1}{l}{$\begin{array}{l}\text { Std. } \\
\text { deviation }\end{array}$} & Min* & Max* \\
\hline Dependent Variables & & & & & \\
\hline Leverage & & 0.6112 & 0.3019 & 0.000 & 1.001 \\
Ownership Share & $\begin{array}{l}\text { Debt/ Total Capital } \\
\text { Share of affiliate's equity } \\
\text { held by German mother }\end{array}$ & 0.7844 & 0.3447 & 0.000 & 1.000 \\
& & & & & \\
& & & & & \\
Independent Variables & & & & & \\
(firm-level) & & & & & \\
\hline Fixed/ Total Assets & & 0.2497 & 0.2695 & 0.0000 & 1.000 \\
Log( Sales) & 9.1442 & 1.5031 & 6.9078 & 17.4813 \\
Profit/ Total Assets & & 0.0251 & 0.2379 & -13.5080 & 27.4530 \\
Retained Profits/ Total & & 0.0574 & 0.1393 & 0.0000 & 1.000
\end{tabular}

Assets

Independent Variables

(country-level)

\begin{tabular}{llrrrr}
\hline Inflation & 4.163699 & 15.1492 & -29.2000 & 1061.2000 \\
Log(GDP) & 6.1387 & 1.5981 & -1.3174 & 9.3703 \\
Log(GDP per Capita) & & 9.6279 & 1.0499 & 4.4938 & 11.1656 \\
Political Risk & $\begin{array}{l}\text { Index between zero and one } \\
\text { with a higher index } \\
\text { reflecting higher political }\end{array}$ & 0.1875 & 0.0880 & 0.0392 & 0.7474 \\
& $\begin{array}{l}\text { risk. } \\
\text { Ratio of private credit lent } \\
\text { Pyivate Credit }\end{array}$ & 0.8144 & 0.4090 & 0.0130 & 1.7850 \\
& $\begin{array}{l}\text { by deposit money banks to } \\
\text { total GDP }\end{array}$ & & & & \\
Statutory Tax & & 33.7706 & 6.3533 & 10.0000 & 53.0000
\end{tabular}

*Averaged over three affiliates 
Table 2

The Impact of Political Risk on Affiliate Leverage and Ownership Share

\begin{tabular}{lcccc} 
& $(1)$ & $(2)$ & $(3)$ & $(4)$ \\
Dependent Variable & Leverage & Leverage & Ownership & Ownership \\
& & & & \\
\hline Political Risk & $0.1227^{* * *}$ & $0.1393^{* * *}$ & $-0.1207^{* * *}$ & $-0.1260^{* * *}$ \\
& $(0.0176)$ & $(0.0191)$ & $(0.0135)$ & $(0.0141)$ \\
Log (Sales) & $0.0046^{* * *}$ & $0.0049^{* * *}$ & $-0.0057^{* * *}$ & $-0.0052^{* * *}$ \\
& $(0.0016)$ & $(0.0016)$ & $(0.0007)$ & $(0.0007)$ \\
Profit/ Total Assets & $-0.3245^{* * *}$ & $-0.3122^{* * *}$ & $-0.0149 * * *$ & $-0.0134^{* * *}$ \\
& $(0.0534)$ & $(0.0539)$ & $(0.0037)$ & $(0.0036)$ \\
Fixed Assets & $-0.0981^{* * *}$ & $-0.0867^{* * *}$ & $-0.0222^{* * *}$ & $-0.0267^{* * *}$ \\
& $(0.0062)$ & $(0.0063)$ & $(0.0040)$ & $(0.0041)$ \\
Private Credit & $-0.0385^{* * *}$ & $-0.0367^{* * *}$ & $-0.0342^{* * *}$ & $-0.0366^{* * *}$ \\
& $(0.0028)$ & $(0.0029)$ & $(0.0020)$ & $(0.0021)$ \\
Inflation & -0.0000 & $-0.0002^{*}$ & 0.0000 & $0.0002^{* *}$ \\
& $(0.0000)$ & $(0.0001)$ & $(0.0000)$ & $(0.0001)$ \\
Log (GDP) & -0.0005 & $-0.0064^{* * *}$ & $-0.0041 * * *$ & $-0.0013^{*}$ \\
& $(0.0010)$ & $(0.0011)$ & $(0.0006)$ & $(0.0007)$ \\
Log (GDP per Capita) & $0.0203^{* * *}$ & $0.0207^{* * *}$ & $0.0289 * * *$ & $0.0264 * * *$ \\
& $(0.0017)$ & $(0.0018)$ & $(0.0014)$ & $(0.0015)$ \\
Statutory Tax & & $0.0027^{* * *}$ & & $-0.0013^{* * *}$ \\
& & $(0.0002)$ & & $(0.0001)$ \\
Observations & 105875 & 98880 & 105875 & 98880 \\
Number of mothers & 11238 & 11050 & 11238 & 11050 \\
R-Squared & 0.12 & 0.12 & 0.05 & 0.04 \\
& & & &
\end{tabular}

OLS Regression including mother fixed effects

Year and affiliate industry dummies included in regression

Standard errors in parentheses

$* * * \mathrm{p}<0.01,{ }^{* *} \mathrm{p}<0.05, * \mathrm{p}<0.1$

Datasources: Firm-level variables are taken from the Microdatabase Direct Investment of the German Bundesbank. Private Credit is provided in Beck et al. (1999). Inflation, Log of GDP, Log of GDP per capita are taken from the IMF. Statutory Tax rates are taken from the IFS, as well as from the Corporate Tax Guides of Ernst\&Young, KPMG and Pricewaterhouse Coopers . 
Table 3

Instrumental Variables Regression

Leverage Instrumented by Retained Profits

\begin{tabular}{lcc} 
& $(1)$ & $(2)$ \\
Dependent Variable & Ownership & Ownership \\
& & \\
\hline Political Risk & $-0.1364^{* * *}$ & $-0.1405^{* * *}$ \\
& $(0.0135)$ & $(0.0140)$ \\
Leverage & $0.1275^{* * *}$ & $0.1044^{* * *}$ \\
& $(0.0103)$ & $(0.0103)$ \\
Log (Sales) & $-0.0063^{* * *}$ & $-0.0057^{* * *}$ \\
& $(0.0007)$ & $(0.0007)$ \\
Profit/ Total Assets & $0.0264^{* * *}$ & $0.0192^{* * *}$ \\
& $(0.0060)$ & $(0.0053)$ \\
Fixed Assets & $-0.0097^{* *}$ & $-0.0176^{* * *}$ \\
& $(0.0041)$ & $(0.0042)$ \\
Private Credit & $-0.0292^{* * *}$ & $-0.0328^{* * *}$ \\
& $(0.0020)$ & $(0.0021)$ \\
Inflation & 0.0000 & $0.0003^{* *}$ \\
& $(0.0000)$ & $(0.0001)$ \\
Log (GDP) & $-0.0041^{* * *}$ & -0.0006 \\
& $(0.0006)$ & $(0.0007)$ \\
Log (GDP per Capita) & $0.0263^{* * *}$ & $0.0242^{* * *}$ \\
& $(0.0014)$ & $(0.0015)$ \\
Statutory Tax & & $-0.0016^{* * *}$ \\
& & $(0.0001)$ \\
Observations & 104242 & 97217 \\
Number of mothers & 9605 & 9387
\end{tabular}

OLS Regression including mother fixed effects

Year and affiliate industry dummies included in regression Standard errors in parentheses

$* * * \mathrm{p}<0.01, * * \mathrm{p}<0.05, * \mathrm{p}<0.1$

Datasources: Firm-level variables are taken from the Microdatabase Direct Investment of the German Bundesbank. Private Credit is provided in Beck et al. (1999). Inflation, Log of GDP, Log of GDP per capita are taken from the IMF. Statutory Tax rates are taken from the IFS, as well as from the Corporate Tax Guides of Ernst\&Young, KPMG and Pricewaterhouse Coopers . 
Table 4

The Impact of Political Risk on Affiliate Leverage and Ownership Share

Political Risk below the median

\begin{tabular}{lcccc} 
& $(1)$ & $(2)$ & $(3)$ & $(4)$ \\
Dependent Variable & Leverage & $\begin{array}{c}(2) \\
\text { Leverage }\end{array}$ & Ownership & Ownership \\
& & & & \\
\hline Political Risk & $0.1756^{* * *}$ & $0.1306^{* *}$ & $-0.0839^{* *}$ & $-0.0678^{*}$ \\
& $(0.0519)$ & $(0.0534)$ & $(0.0353)$ & $(0.0361)$ \\
Log (Sales) & 0.0032 & 0.0032 & $-0.0065^{* * *}$ & $-0.0066^{* * *}$ \\
& $(0.0020)$ & $(0.0020)$ & $(0.0011)$ & $(0.0011)$ \\
Profit/ Total Assets & $-0.2344^{* * *}$ & $-0.2294^{* * *}$ & $-0.0052^{*}$ & $-0.0053^{*}$ \\
& $(0.0590)$ & $(0.0580)$ & $(0.0031)$ & $(0.0032)$ \\
Fixed Assets & $-0.0358^{* * *}$ & $-0.0339^{* * *}$ & $-0.0195^{* * *}$ & $-0.0192^{* * *}$ \\
& $(0.0090)$ & $(0.0090)$ & $(0.0060)$ & $(0.0061)$ \\
Private Credit & $-0.0498^{* * *}$ & $-0.0524^{* * *}$ & 0.0017 & 0.0019 \\
& $(0.0043)$ & $(0.0044)$ & $(0.0029)$ & $(0.0029)$ \\
Inflation & $-0.0083^{* * *}$ & $-0.0085^{* * *}$ & $0.0014^{* * *}$ & $0.0010^{*}$ \\
& $(0.0008)$ & $(0.0009)$ & $(0.0005)$ & $(0.0006)$ \\
Log (GDP) & -0.0002 & $-0.0032^{* *}$ & $0.0024 * * *$ & $0.0060^{* * *}$ \\
& $(0.0014)$ & $(0.0016)$ & $(0.0009)$ & $(0.0010)$ \\
Log (GDP per Capita) & $-0.0312^{* * *}$ & $-0.0344^{* * *}$ & 0.0019 & -0.0012 \\
& $(0.0052)$ & $(0.0056)$ & $(0.0036)$ & $(0.0038)$ \\
Statutory Tax & & $0.0020^{* * *}$ & & $-0.0016^{* * *}$ \\
& & $(0.0003)$ & & $(0.0002)$ \\
Observations & 50829 & 49540 & 50829 & 49540 \\
Number of mothers & 8483 & 8408 & 8483 & 8408 \\
R-squared & 0.10 & 0.10 & 0.02 & 0.02
\end{tabular}

OLS Regression including mother fixed effects

Year and affiliate industry dummies included in regression

Standard errors in parentheses

$* * * \mathrm{p}<0.01,{ }^{* *} \mathrm{p}<0.05, * \mathrm{p}<0.1$

Datasources: Firm-level variables are taken from the Microdatabase Direct Investment of the German Bundesbank. Private Credit is provided in Beck et al. (1999). Inflation, Log of GDP, Log of GDP per capita are taken from the IMF. Statutory Tax rates are taken from the IFS, as well as from the Corporate Tax Guides of Ernst\&Young, KPMG and Pricewaterhouse Coopers . 
Table 5

Instrumental Variables Regression

Leverage Instrumented by Retained Profits

Political Risk below the median

(1)

(2)

\begin{tabular}{lcc} 
Dependent Variable & Ownership & Ownership \\
\hline Political Risk & $-0.1068^{* * *}$ & $-0.0841^{* *}$ \\
& $(0.0352)$ & $(0.0359)$ \\
Leverage & $0.1302^{* * *}$ & $0.1246^{* * *}$ \\
& $(0.0157)$ & $(0.0161)$ \\
Log (Sales) & $-0.0069^{* * *}$ & $-0.0070^{* * *}$ \\
& $(0.0011)$ & $(0.0011)$ \\
Profit/ Total Assets & $0.0254^{* * *}$ & $0.0233^{* * *}$ \\
& $(0.0076)$ & $(0.0071)$ \\
Fixed Assets & $-0.0148^{* *}$ & $-0.0150^{* *}$ \\
& $(0.0060)$ & $(0.0061)$ \\
Private Credit & $0.0082^{* * *}$ & $0.0084^{* * *}$ \\
& $(0.0030)$ & $(0.0030)$ \\
Inflation & $0.0025^{* * *}$ & $0.0021^{* * *}$ \\
& $(0.0005)$ & $(0.0006)$ \\
Log (GDP) & $0.0025^{* * *}$ & $0.0063^{* * *}$ \\
& $(0.0009)$ & $(0.0010)$ \\
Log (GDP per Capita) & 0.0059 & 0.0031 \\
& $(0.0036)$ & $(0.0038)$ \\
Statutory Tax & & $-0.0018^{* * *}$ \\
& & $(0.0002)$ \\
Observations & 49198 & 47932 \\
Number of mothers & 6852 & 6800
\end{tabular}

OLS Regression including mother fixed effects

Year and affiliate industry dummies included in regression

Standard errors in parentheses

$* * * \mathrm{p}<0.01,{ }^{* *} \mathrm{p}<0.05, * \mathrm{p}<0.1$

Datasources: Firm-level variables are taken from the Microdatabase Direct Investment of the German Bundesbank. Private Credit is provided in Beck et al. (1999). Inflation, Log of GDP, Log of GDP per capita are taken from the IMF. Statutory Tax rates are taken from the IFS, as well as from the Corporate Tax Guides of Ernst\&Young, KPMG and Pricewaterhouse Coopers . 
Table 6

The Impact of Political Risk on Affiliate Leverage and Ownership Share

Political Risk above the median

\begin{tabular}{lcccc} 
& $(1)$ & $(2)$ & $(3)$ & $(4)$ \\
Dependent Variable & Leverage & Leverage & Ownership & Ownership \\
& & & & \\
\hline Political Risk & $0.0686^{* *}$ & $0.0697^{* *}$ & $-0.1639^{* * *}$ & $-0.1771^{* * *}$ \\
& $(0.0266)$ & $(0.0318)$ & $(0.0235)$ & $(0.0272)$ \\
Log (Sales) & $0.0075^{* * *}$ & $0.0083^{* * *}$ & $-0.0057^{* * *}$ & $-0.0048^{* * *}$ \\
& $(0.0014)$ & $(0.0015)$ & $(0.0011)$ & $(0.0011)$ \\
Profit/ Total Assets & $-0.4756^{* * *}$ & $-0.4666^{* * *}$ & $-0.0310^{* * *}$ & $-0.0258^{* * *}$ \\
& $(0.0311)$ & $(0.0350)$ & $(0.0063)$ & $(0.0068)$ \\
Fixed Assets & $-0.1489^{* * *}$ & $-0.1307^{* * *}$ & $-0.0232^{* * *}$ & $-0.0312^{* * *}$ \\
& $(0.0080)$ & $(0.0085)$ & $(0.0059)$ & $(0.0063)$ \\
Private Credit & $-0.0248^{* * *}$ & $-0.0130^{* * *}$ & $-0.0404^{* * *}$ & $-0.0519^{* * *}$ \\
& $(0.0044)$ & $(0.0050)$ & $(0.0034)$ & $(0.0040)$ \\
Inflation & 0.0000 & 0.0000 & 0.0000 & 0.0001 \\
& $(0.0000)$ & $(0.0002)$ & $(0.0000)$ & $(0.0001)$ \\
Log (GDP) & -0.0019 & $-0.0093^{* * *}$ & $-0.0086^{* * *}$ & $-0.0053^{* * *}$ \\
& $(0.0013)$ & $(0.0015)$ & $(0.0010)$ & $(0.0012)$ \\
Log (GDP per Capita) & $0.0177^{* * *}$ & $0.0198^{* * *}$ & $0.0347 * * *$ & $0.0310^{* * *}$ \\
& $(0.0021)$ & $(0.0024)$ & $(0.0020)$ & $(0.0021)$ \\
Statutory Tax & & $0.0025^{* * *}$ & & $-0.0012^{* * *}$ \\
& & $(0.0002)$ & & $(0.0002)$ \\
Observations & 59340 & 55046 & 49340 \\
Number of mothers & 8605 & 8254 & 8605 & 8254 \\
R-squared & 0.16 & 0.16 & 0.07 & 0.06
\end{tabular}

OLS Regression including mother fixed effects

Year and affiliate industry dummies included in regression

Standard errors in parentheses

${ }^{* * *} \mathrm{p}<0.01,{ }^{* *} \mathrm{p}<0.05, * \mathrm{p}<0.1$

Datasources: Firm-level variables are taken from the Microdatabase Direct Investment of the German Bundesbank. Private Credit is provided in Beck et al. (1999). Inflation, Log of GDP, Log of GDP per capita are taken from the IMF. Statutory Tax rates are taken from the IFS, as well as from the Corporate Tax Guides of Ernst\&Young, KPMG and Pricewaterhouse Coopers . 
Table 7

Instrumental Variables Regression

Leverage Instrumented by Retained Profits

Political Risk above the median

(1)

(2)

\begin{tabular}{lcc} 
Dependent Variable & Ownership & Ownership \\
\hline Political Risk & $-0.1740^{* * *}$ & $-0.1844^{* * *}$ \\
& $(0.0232)$ & $(0.0265)$ \\
Leverage & $0.1471^{* * *}$ & $0.1043^{* * *}$ \\
& $(0.0154)$ & $(0.0153)$ \\
Log (Sales) & $-0.0068^{* * *}$ & $-0.0057^{* * *}$ \\
& $(0.0010)$ & $(0.0011)$ \\
Profit/ Total Assets & $0.0390^{* * *}$ & $0.0229^{* *}$ \\
& $(0.0100)$ & $(0.0098)$ \\
Fixed Assets & -0.0013 & $-0.0176^{* * *}$ \\
& $(0.0063)$ & $(0.0065)$ \\
Private Credit & $-0.0368^{* * *}$ & $-0.0505^{* * *}$ \\
& $(0.0034)$ & $(0.0039)$ \\
Inflation & 0.0000 & 0.0001 \\
& $(0.0000)$ & $(0.0001)$ \\
Log (GDP) & $-0.0083^{* * *}$ & $-0.0043^{* * *}$ \\
& $(0.0010)$ & $(0.0011)$ \\
Log (GDP per Capita) & $0.0321^{* * *}$ & $0.0290^{* * *}$ \\
& $(0.0019)$ & $(0.0020)$ \\
Statutory Tax & & $-0.0014^{* * *}$ \\
& & $(0.0002)$ \\
Observations & 52847 & 47211 \\
Number of mothers & 6406 & 6125
\end{tabular}

OLS Regression including mother fixed effects

Year and affiliate industry dummies included in regression Standard errors in parentheses $* * * \mathrm{p}<0.01, * * \mathrm{p}<0.05, * \mathrm{p}<0.1$

Datasources: Firm-level variables are taken from the Microdatabase Direct Investment of the German Bundesbank. Private Credit is provided in Beck et al. (1999). Inflation, Log of GDP, Log of GDP per capita are taken from the IMF. Statutory Tax rates are taken from the IFS, as well as from the Corporate Tax Guides of Ernst\&Young, KPMG and Pricewaterhouse Coopers . 
Table 8

The Impact of Political Risk on Affiliate Leverage and Ownership Share

\begin{tabular}{|c|c|c|c|c|}
\hline Dependent Variable & $\begin{array}{c}\text { (1) } \\
\text { Leverage }\end{array}$ & $\begin{array}{c}\text { (2) } \\
\text { Leverage }\end{array}$ & $\begin{array}{c}\text { (3) } \\
\text { Ownership }\end{array}$ & $\begin{array}{c}\text { (4) } \\
\text { Ownership }\end{array}$ \\
\hline Political Risk & $\begin{array}{c}-0.1745^{* *} \\
(0.0806)\end{array}$ & $\begin{array}{c}-0.3977 * * * \\
(0.0882)\end{array}$ & $\begin{array}{c}-1.0663 * * * \\
(0.0687)\end{array}$ & $\begin{array}{c}-0.8748 * * * \\
(0.0738)\end{array}$ \\
\hline Log (Sales) & $\begin{array}{c}0.0045^{* * *} \\
(0.0016)\end{array}$ & $\begin{array}{c}0.0048 * * * \\
(0.0016)\end{array}$ & $\begin{array}{c}-0.0059 * * * \\
(0.0007)\end{array}$ & $\begin{array}{c}-0.0053^{* * *} \\
(0.0007)\end{array}$ \\
\hline Profit/ Total Assets & $\begin{array}{c}-0.3244 * * * \\
(0.0534)\end{array}$ & $\begin{array}{c}-0.3119 * * * \\
(0.0538)\end{array}$ & $\begin{array}{c}-0.0145 * * * \\
(0.0036)\end{array}$ & $\begin{array}{c}-0.0130 * * * \\
(0.0035)\end{array}$ \\
\hline Fixed Assets & $\begin{array}{c}-0.0980 * * * \\
(0.0062)\end{array}$ & $\begin{array}{c}-0.0864 * * * \\
(0.0063)\end{array}$ & $\begin{array}{c}-0.0218 * * * \\
(0.0040)\end{array}$ & $\begin{array}{c}-0.0262 * * * \\
(0.0041)\end{array}$ \\
\hline Private Credit & $\begin{array}{c}-0.0359 * * * \\
(0.0028)\end{array}$ & $\begin{array}{c}-0.0317 * * * \\
(0.0029)\end{array}$ & $\begin{array}{c}-0.0258 * * * \\
(0.0021)\end{array}$ & $\begin{array}{c}-0.0296 * * * \\
(0.0022)\end{array}$ \\
\hline Inflation & $\begin{array}{c}-0.0000 \\
(0.0000)\end{array}$ & $\begin{array}{l}-0.0002 \\
(0.0001)\end{array}$ & $\begin{array}{c}0.0000 \\
(0.0000)\end{array}$ & $\begin{array}{c}0.0003 * * * \\
(0.0001)\end{array}$ \\
\hline Log (GDP) & $\begin{array}{l}-0.0002 \\
(0.0010)\end{array}$ & $\begin{array}{c}-0.0058 * * * \\
(0.0011)\end{array}$ & $\begin{array}{c}-0.0031 * * * \\
(0.0006)\end{array}$ & $\begin{array}{l}-0.0006 \\
(0.0007)\end{array}$ \\
\hline $\begin{array}{l}\text { Log (GDP per } \\
\text { Capita) }\end{array}$ & $(0.0029)$ & $\begin{array}{c}0.0046 \\
(0.0031)\end{array}$ & $(0.0024)$ & $\begin{array}{c}0.0039 \\
(0.0026)\end{array}$ \\
\hline $\begin{array}{l}\text { Political Risk * } \\
\text { GDP per capita }\end{array}$ & $0.0330 * * *$ & $0.0592 * * *$ & $0.1049 * * *$ & $0.0825 * * *$ \\
\hline Statutory Tax & & $\begin{array}{c}0.0028 * * * \\
(0.0002)\end{array}$ & & $\begin{array}{c}-0.0012 * * * \\
(0.0001)\end{array}$ \\
\hline Observations & 105875 & 98880 & 105875 & 98880 \\
\hline Number of mothers & 11238 & 11050 & 11238 & 11050 \\
\hline R-Squared & 0.12 & 0.12 & 0.05 & 0.04 \\
\hline
\end{tabular}

Datasources: Firm-level variables are taken from the Microdatabase Direct Investment of the German Bundesbank. Private Credit is provided in Beck et al. (1999). Inflation, Log of GDP, Log of GDP per capita are taken from the IMF. Statutory Tax rates are taken from the IFS, as well as from the Corporate Tax Guides of Ernst\&Young, KPMG and Pricewaterhouse Coopers . 
Table 9

Instrumental Variables Regression

Leverage Instrumented by Retained Profits

(1)

(2)

\begin{tabular}{lcc} 
Dependent Variable & Ownership & Ownership \\
\hline Political Risk & $-1.0442^{* * *}$ & $-0.8330^{* * *}$ \\
Leverage & $(0.0686)$ & $(0.0733)$ \\
& $0.1267^{* * *}$ & $0.1050^{* * *}$ \\
Log (Sales) & $(0.0102)$ & $(0.0102)$ \\
& $-0.0065^{* * *}$ & $-0.0058^{* * *}$ \\
Profit/ Total Assets & $(0.0007)$ & $(0.0007)$ \\
& $0.0266^{* * *}$ & $0.0197^{* * *}$ \\
Fixed Assets & $(0.0061)$ & $(0.0054)$ \\
& $-0.0094^{* *}$ & $-0.0172^{* * *}$ \\
Private Credit & $(0.0041)$ & $(0.0042)$ \\
& $-0.0212^{* * *}$ & $-0.0263^{* * *}$ \\
Inflation & $(0.0021)$ & $(0.0022)$ \\
& 0.0000 & $0.0003^{* * *}$ \\
Log (GDP) & $(0.0000)$ & $(0.0001)$ \\
& $-0.0031^{* * *}$ & 0.0000 \\
Log (GDP per Capita) & $(0.0006)$ & $(0.0007)$ \\
& -0.0014 & 0.0034 \\
Political Risk * GDP per capita & $(0.0024)$ & $(0.0025)$ \\
& $0.1007^{* * *}$ & $0.0763^{* * *}$ \\
Statutory Tax & $(0.0074)$ & $(0.0078)$ \\
& & $-0.0015^{* * *}$ \\
Observations & & $(0.0001)$ \\
Number of mothers & 104242 & 97217 \\
& 9605 & 9387
\end{tabular}

OLS Regression including mother fixed effects

Year and affiliate industry dummies included in regression

Standard errors in parentheses

$* * * \mathrm{p}<0.01,{ }^{* *} \mathrm{p}<0.05,{ }^{*} \mathrm{p}<0.1$

Datasources: Firm-level variables are taken from the Microdatabase Direct Investment of the German Bundesbank. Private Credit is provided in Beck et al. (1999). Inflation, Log of GDP, Log of GDP per capita are taken from the IMF. Statutory Tax rates are taken from the IFS, as well as from the Corporate Tax Guides of Ernst\&Young, KPMG and Pricewaterhouse Coopers . 